\title{
High-Pressure Carbon Dioxide Use to Control Dried Apricot Pests, Tribolium castaneum and Rhyzopertha dominica, and Assessing the Qualitative Traits of Dried Pieces of Treated Apricot
}

\author{
Reza Sadeghi ${ }^{1, *(\mathbb{D})}$, Fereshteh Heidari ${ }^{1}$, Asgar Ebadollahi ${ }^{2, * \mathbb{D}}$, Fatemeh Azarikia ${ }^{3}$, Arsalan Jamshidnia ${ }^{1}$ (D) \\ and Franco Palla 4 ,* \\ 1 Department of Entomology and Plant Pathology, College of Aburaihan, University of Tehran, \\ Tehran 3391653755, Iran; f.heidari4234@gmail.com (F.H.); jamshidnia@ut.ac.ir (A.J.) \\ 2 Department of Plant Sciences, Moghan College of Agriculture and Natural Resources, \\ University of Mohaghegh Ardabili, Ardabil 5619936514, Iran \\ 3 Department of Food Technology, College of Aburaihan, University of Tehran, Tehran 3391653755, Iran; \\ azarikia@ut.ac.ir \\ 4 Department of Biological, Chemical and Pharmaceutical Sciences and Technologies, University of Palermo, \\ 38-90123 Palermo, Italy \\ * Correspondence: rsadeghi@ut.ac.ir (R.S.); ebadollahi@uma.ac.ir (A.E.); franco.palla@unipa.it (F.P.)
}

Citation: Sadeghi, R.; Heidari, F.; Ebadollahi, A.; Azarikia, F. Jamshidnia, A.; Palla, F. High-Pressure Carbon Dioxide Use to Control Dried Apricot Pests, Tribolium castaneum and Rhyzopertha dominica, and Assessing the Qualitative Traits of Dried Pieces of Treated Apricot. Foods 2021, 10, 1190 https://doi.org/10.3390/foods10061190

Academic Editors: Lisa Pilkington, Siew-Young Quek and Susana Casal

Received: 10 April 2021

Accepted: 23 May 2021

Published: 25 May 2021

Publisher's Note: MDPI stays neutra with regard to jurisdictional claims in published maps and institutional affiliations.

Copyright: (c) 2021 by the authors Licensee MDPI, Basel, Switzerland. This article is an open access article distributed under the terms and conditions of the Creative Common Attribution (CC BY) license (https:// creativecommons.org/licenses/by/ $4.0 /)$

\begin{abstract}
One of the new ways of warehouse pest control is the carbon dioxide treatment, which had no residues on the target products. In the present research, at first, $\mathrm{CO}_{2}$ gas was applied to control two important pest species infesting dried apricots. Dry apricots infested with adults of Tribolium castaneum (Herbst) or Rhyzopertha dominica (F.) were exposed to $\mathrm{CO}_{2}$ gas pressures correspond to 9.1, $16.7,23.1,28.6$, and $33.4 \mathrm{~mol} \%$ for $24 \mathrm{~h}$. The results showed higher mortality rates with increasing the gas pressures in all the experiments. The minimum and maximum losses of the pests were determined at concentrations of 9.1 and $33.4 \mathrm{~mol} \%$, respectively. Evaluation of $\mathrm{CO}_{2}$ gas effects on the quality characteristics of dried apricots showed no impacts on the color, brittleness, hardness, sweetness, sourness, and general acceptance of products. $\mathrm{CO}_{2}$ gas treatments at the concentration of $33.4 \mathrm{~mol} \%$ showed no significant influences on the chemical features of dried apricots, including $\mathrm{pH}$, acidity, Brix, humidity percentage, reducing sugar, and total sugar. It was concluded that $\mathrm{CO}_{2}$ gas had the potential to control T. castaneum and R. dominica in warehouses of dried apricots, without any significant impacts on product qualities.
\end{abstract}

Keywords: apricot; $\mathrm{CO}_{2}$ gas; qualitative traits; warehouse pest

\section{Introduction}

Apricot, Prunus armeniaca L. (Rosales: Rosaceae), is considered as one of the most delicious fruits in regions with temperate climates. It contains saccharides, organic acids, minerals, vitamins, and polyphenols and has antioxidant properties [1]. Apricot is served fresh or as dried or frozen fruit, compote, extract, and jam [2]. According to the Food and Agriculture Organization (FAO) statistics, Turkey, Uzbekistan, and Iran ranked 1st to 3rd in the world in 2018 for producing 750,000, 493,842, and 342,479 tons of apricot, respectively [3]. Dried fruits are stored in warehouses under specific controlled conditions to maintain their quality and marketability, besides preventing pest infestation. Millions of tons of crops and dried fruits are annually lost because of the damage created by storage pests and the non-observance of scientific storage principles. Heavy quantitative, qualitative, and hygienic damages may be inflicted on storage products by insects [4]. To be supplied to the world markets, agricultural products must satisfy the necessary standards such as acceptable taste and color and particularly moisture content without any infestations of insects [5]. 
Conventional pest management practices provide such advantages as ease of operations and low costs; yet, overuse of synthetic chemicals involves some disadvantages such as prolonging slow operations, producing environmentally polluting and ozone-depleting wastes, imposing health risks on the operators, having adverse impacts on product quality, and so on [6-8]. For instance, methyl bromide has been successfully applied to control a variety of insects over the years, but due to the hazardous environmental impacts its use has been limited by international subsidiary organizations until 2015 [9]. Thus, it is necessary to replace synthetic insecticides with environmentally friendly agents concerning the problems related to chemical insecticides, besides the economic importance of pest control [10]. In previous publications, as an alternative to synthetic pesticides, interests have been focalized on plant essential oils [11,12].

Being a non-flammable and odorless gas with a body mass of 1.5 times the air mass, carbon dioxide $\left(\mathrm{CO}_{2}\right)$ had no residues on target products while also being toxic to insects [13]. A wide range of pests, along with their different growth stages, can be controlled by $\mathrm{CO}_{2}$ gas during the storage of dried fruits [14]. An increase in the amount of $\mathrm{CO}_{2}$ would lead to enhancement of the respiratory rates of insects. Therefore, in warehouses, insects can be killed even at low $\mathrm{CO}_{2}$ concentrations, which results in the disruption of their breathing regulations when it enters their body tissues and fluid organs [15]. Additionally, respiratory pores of insects may be kept open at the concentration of $35 \% \mathrm{CO}_{2}$, which can force extra water uptakes of their cellular tissues and impair the metabolism of organs by reducing amounts of triglycerides; these conditions would consequently lead to their mortalities [16]. Effectiveness of $\mathrm{CO}_{2}$ in the control of stored-product insect pests was assessed in the previous studies. For example, Cheng et al. [17] used a mixture of $2 \%$ oxygen and $18 \%$ carbon dioxide, which could stop all the growth stages of cowpea weevil, Callosobruchus maculatus F. In their study, Valizadegan et al. [18] were able to control four species of storage pests with a combination of phosphine and carbon dioxide, which provided the advantage of reduced phosphine consumption. Complete controls of the insects were achieved within 7, 10, and 11 weeks after 24 h-treatment. Carbon monoxide and dioxide efficacies were investigated by Dhouibi et al. [19] for controlling flour and carob moths (Ephestia kuehniella Zeller and Ectomyelois ceratoniae Zeller, respectively) infesting organic dates. Mortality of all tested insects was achieved by 5.5 and $2.8 \mathrm{~kg} / \mathrm{m}^{3}$ of $\mathrm{CO}_{2}$ fumigations after 20 and $48 \mathrm{~h}$ under laboratory and field conditions, respectively.

The color lab space was designed in a way to be very similar to what is perceived by human vision [20]. In the image processing technique, the parameters of $\mathrm{L}^{*}, \mathrm{a}^{*}$, and $\mathrm{b}^{*}$ indicate brightness, redness, and yellowness of products, respectively, which can be changed in the treatments by pest control and preserving agents [21]. For example, Sadeghi et al. [22] reported increasing $\mathrm{L}^{*}, \mathrm{a}^{*}$, and $\mathrm{b}^{*}$ variations for figs and raisins with enhancing microwave powers and timings in the sawtoothed grain beetle (Oryzaephilus surinamensis L.) management. Additionally, Inserra et al. [23] observed an increase in $L^{*}$ and $b^{*}$ and a reduction in $a^{*}$ parameters of apricots treated with sulfur before drying.

Although the red flour beetle (Tribolium castaneum Herbst) and the lesser grain borer (Rhyzopertha dominica (F.)) are among the cosmopolitan insect pests of stored flour and grains, they can damage dried material of animal and plant origin such as dried fruits [24,25]. This study aimed to (1) determine the effect of high-pressure $\mathrm{CO}_{2}$ on the mortality of two cosmopolitan stored-products insect pests T. castaneum and $R$. dominica and (2) investigate possible changes in sensory (organoleptic) and chemical properties of dried apricot affected after treatment by $\mathrm{CO}_{2}$.

\section{Materials and Methods}

\subsection{Dried Fruit and Rearing Insect Pests}

The stored product used in present investigation was dried apricot (Prunus armeniaca L., Shahroudi cultivar) purchased from the wholesale dried fruit market in Tehran City, Iran. R. dominica and T. castaneum, which had been previously reared for ten generations, were prepared in the Toxicology Laboratory of the Department of Entomology and Plant 
Pathology, College of Aburaihan, University of Tehran, Iran. The $1.5 \mathrm{~kg}$ of the two food compositions of broken cereal [26] and intact wheat grains [27] were utilized for breeding $T$. castaneum and R. dominica, respectively. Then, 200 insects of each pest (without sex separation) were released in 3-L plastic containers to be reared at the temperature of $27 \pm 2{ }^{\circ} \mathrm{C}$, relative humidity of $65 \% \pm 5 \%$, and light: dark of $10: 14 \mathrm{~h}$ [28]. Afterward, a brush was used to remove 50 insects from the permanent foodstuff and place them on the rearing food in new containers. Adults were then separated and transferred to the main dish to avoid generational intermingling after a week of mating and spawning. After 27 days, the next adults of the insects appeared and 1-10 day-old adults were used in the experiments.

\subsection{Fumigation of Carbon Dioxide}

The pressures of $\mathrm{CO}_{2}$ gas, which was provided by 20-L capsules, were determined by the equipped pressure gauge during the preliminary tests. The experiment was laid out in a completely randomized design (CRD) with ten replications. Disposable paper cups, with the diameter and height of 7.5 and $8.7 \mathrm{~cm}$, respectively, were used to hold $30 \mathrm{~g}$ of the dried apricot samples contaminated with twenty pests. After transferring the containers of each treatment to a cylindrical autoclave (Kavush Mega Medical Instrument Co., Tehran, Iran) with a 10-L stainless steel tank equipped with a pressure gauge, $\mathrm{CO}_{2}$ inlet and outlet valves, and closable steel lids to confine $\mathrm{CO}_{2}$, the lids were covered with lace and elastic bands. Air inside the autoclave was allowed to completely exit by opening the outlet valve after $20 \mathrm{~s}$ of fumigation. Then, the valve closed and fumigation was prolonged at the specified pressures from 0.1 to 0.5 bar correspond to $9.1,16.7,23.1,28.6$, and $33.4 \mathrm{~mol} \%$. Finally, $24 \mathrm{~h}$ after $\mathrm{CO}_{2}$ fumigation and aeration, the mortality of adult insects was counted. The control treatments underwent no pressure of $\mathrm{CO}_{2}$ gas.

\subsection{Qualitative Properties}

The samples of the dried apricot were studied for organoleptic properties, including color, aroma, sweetness, sourness, brittleness, hardness, and general acceptance, before and after $\mathrm{CO}_{2}$ treatments. Ten expert evaluators ( 5 males and 5 females) confirmed in the taste validity test according to the standards [29] were employed to assess the characteristics. The sensory properties of the apricot specimens were judged by the evaluators using the 7-point hedonic test. The numerical scales of 1-7 (higher qualitative levels with increasing numbers) were recorded in their given forms expressing the intensity of each qualitative attribute. The treated samples were then compared with the five control samples poured into the plastic containers. The evaluators were also provided with some disposable cups of mineral water to avoid interfering with the tastes of the samples between each detection step. These experiments were also arranged in a completely randomized design (CRD) in ten replications.

A digital camera (OLIMPUS VR-310, Tokyo, Japan) was employed to take photos of the pieces of apricots. An artificial lighting system was utilized to provide a uniform lighting condition for the specimens. It was done by using a white fluorescent lamp mounted under the ceiling of our special chamber, the walls of which were covered with a black cover. Photographing was performed at a distance of $30 \mathrm{~cm}$ from the specimens put against a white background [22]. The images were captured at 959 pixels $\times 1280$ pixels and a resolution of $96 \mathrm{dpi}$ in Jpeg format and RGB color space. Image $1.50 \mathrm{v}$ software was applied to process the images captured by the digital camera.

\subsection{Determination of Chemical Properties}

First, the 3-g samples of the apricot pieces, in five replications and pretreated with $\mathrm{CO}_{2}$ gas at the concentration of $33.4 \mathrm{~mol} \%$, were stirred in $20 \mathrm{~mL}$ of distilled water using a magnetic stirrer at $80^{\circ} \mathrm{C}$. After $2 \mathrm{~h}$, the liquid part was separated by filter paper [23]. To determine $\mathrm{pH}$ and Brix number, a $\mathrm{pH}$ meter and a refractometer were employed, respectively. 
To specify the acidity, $10 \mathrm{~mL}$ of the prepared solution in five replications was titrated with $\mathrm{NaOH}(0.1 \mathrm{M})$ until obtaining a pale pink color $(\mathrm{pH}=8.3)$. The results were reported in terms of dominant acid percentage: malic acid [23].

To delineate the moisture content, $3 \mathrm{~g}$ of the samples (in three replications) were placed in a glass plate heated by an oven to $80{ }^{\circ} \mathrm{C}$ for $18 \mathrm{~h}$, and the percentage of moisture content was determined by dividing the difference of the sample weights before and after heating [30].

To determine the reducing sugar, $3 \mathrm{~g}$ of the sample (in three replications) were first mixed with $40 \mathrm{~mL}$ of distilled water at $80^{\circ} \mathrm{C}$ and was filtered through filter paper after $2 \mathrm{~h}$. Then, $5 \mathrm{~mL}$ of Fehling A and Fehling B together with a magnet and about $10 \mathrm{~mL}$ of distilled water were poured into a 100-mL Erlenmeyer flask. Afterward, the Erlen was placed on a magnetic stirrer with a heater and slowly titrated with the sugar solution until fading the blue color and appearing the brick color [31].

To specify total sugar, $25 \mathrm{~mL}$ of the filtered solution was first poured into a $100-\mathrm{mL}$ volumetric flask and $5 \mathrm{~mL}$ of concentrated hydrochloric acid (37\%) was added to it to be then heated in a boiling water bath (Bain Marie) at $65^{\circ} \mathrm{C}$ for $10 \mathrm{~min}$. After reaching ambient temperature, 2 drops of phenol phethalene reagent were added to the mixture, which was then neutralized with $45 \%$ concentrated sodium hydroxide $(0.1)$ to give a pale pink color. Finally, it was volumized with distilled water and then titrated with the prepared sugar solution according to the method described for reducing sugar [31]. This experiment was also performed in three replications. All experiments about the evaluation of chemical properties of dried apricots were arranged in a completely randomized design (CRD).

\subsection{Statistical Analysis}

The Kolmogorov-Smirnov test was used to check the normality of the data. Analysis of variance (ANOVA) was used to determine the statistical effect of $\mathrm{CO}_{2}$ pressures on insect pests. Differences between means were assessed using the Tukey HSD test at $p<0.05$. When any death was observed in the control groups, mortality percentages were corrected using Abbott's formula [32]. Lethal concentration values $\left(\mathrm{LC}_{50}\right.$ and $\mathrm{LC}_{90}$ with their $95 \%$ fiducial limits) and the regression line particulars were calculated using Probit analysis. All statistical analyses were performed with SPSS version 25 (IBM, Chicago, IL, USA). Evaluation of chemical properties $(\mathrm{pH}$, acidity, Brix, total sugar, reducing sugar, and moisture) between treated and untreated dried apricot samples were compared using the $t$-test. A non-parametric Friedman's test used for sensory assessment.

\section{Results}

The adults of $R$. dominica and T. castaneum were highly susceptible to the fumigation of $\mathrm{CO}_{2}$. According to the results of the analysis of variance, the mortality of $R$. dominica and $T$. castaneum adults was statistically affected by different concentrations of $\mathrm{CO}_{2}$. As can be seen in Table 1, the increasing $\mathrm{CO}_{2}$ concentration were associated with the enhanced mortality of the both insects. The $\mathrm{CO}_{2}$ concentration of $33.4 \mathrm{~mol} \%$ caused 90 and $78 \%$ mortality of the adults of $R$. dominica and T. castaneum, respectively (Table 1).

Along with the high mortality of $R$. dominica at all tested concentrations of $\mathrm{CO}_{2}$, the calculated $\mathrm{LC}_{50}$ value $(20.19 \mathrm{~mol} \%)$ for this pest was also lower than that corresponding value for T. castaneum (27.02 mol\%). However, based on the overlapping of their fiducial limits, the susceptibility of these insects to $\mathrm{CO}_{2}$ was not significantly different (Table 2). Additionally, according to the $R^{2}$ values in Table 2, there was a direct and positive relationship between the tested $\mathrm{CO}_{2}$ concentrations and the observed mortality of both insects. 
Table 1. Means \pm standard errors of the mortality rates of T. castaneum and $R$. dominica at different $\mathrm{CO}_{2}$ pressures.

\begin{tabular}{ccc}
\hline $\begin{array}{c}\text { Concentration } \\
\text { (mol\%) }\end{array}$ & \multicolumn{2}{c}{ Mortality Percentage + SE } \\
\cline { 2 - 3 } & T. castaneum $^{\text {c }}$ & . dominica \\
\hline Control $=0$ & $1.00 \pm 0.667^{\mathrm{a}}$ & $3.50 \pm 1.302^{\mathrm{a}}$ \\
9.1 & $5.50 \pm 1.167^{\mathrm{a}}$ & $23.00 \pm 1.106^{\mathrm{b}}$ \\
16.7 & $9.50 \pm 1.572^{\mathrm{a}}$ & $44.00 \pm 2.667^{\mathrm{c}}$ \\
23.1 & $27.50 \pm 3.184^{\mathrm{b}}$ & $57.50 \pm 2.713^{\mathrm{d}}$ \\
28.6 & $57.00 \pm 1.700^{\mathrm{c}}$ & $80.00 \pm 2.108^{\mathrm{e}}$ \\
33.4 & $78.00 \pm 3.000^{\mathrm{d}}$ & $90.50 \pm 3.114^{\mathrm{f}}$ \\
\hline & $\mathrm{F}=223.54$ & $\mathrm{~F}=210.23$ \\
ANOVA: & $\mathrm{df}=5,54^{*}$ & $\mathrm{df}=5,54$ \\
& $p=0<0.001^{*}$ & $p=0<0.001^{*}$ \\
\hline
\end{tabular}

Values with different letters within each column are statistically different according to the Tukey's test at $p<0.05$ Asterisks indicate significant effects of $\mathrm{CO}_{2}$ concentrations on mortality of insect pests, according to the results of the analysis of variance (ANOVA). SE is standard error.

Table 2. Probit analysis of the toxicity of $\mathrm{CO}_{2}$ on the adult-insects of $R$. dominica and T. castaneum.

\begin{tabular}{|c|c|c|c|c|c|c|c|}
\hline Insect & $\begin{array}{c}\text { LC }_{50} \text { with } \\
\text { 95\% Fiducial Limits } \\
\text { (mol\%) }\end{array}$ & $\begin{array}{c}\text { LC }_{90} \text { with } \\
\text { 95\% Fiducial Limits } \\
(\mathrm{mol} \%)\end{array}$ & Intercept $\pm \mathbf{S E}$ & Slope \pm SE & $\begin{array}{c}\chi^{2} \\
(\mathrm{df}=3)\end{array}$ & Sig. & $\begin{array}{c}R^{2} \\
\text { Value }\end{array}$ \\
\hline R. dominica & $20.19(18.37-22.19)$ & $54.45(38.41-131.89)$ & $-3.88 \pm 0.43$ & $2.97 \pm 0.32$ & 5.58 & 0.13 & 0.95 \\
\hline T. castaneum & $27.02(18.42-104.51)$ & $48.26(32.83-5320.19)$ & $-7.21 \pm 0.67$ & $5.03 \pm 0.49$ & 26.19 & $0<0.001$ & 0.87 \\
\hline
\end{tabular}

Number of tested adults for each species was 500. Sig. is significant.

Table 3 shows the means of the sensory characteristics of the dried apricots and their comparison via the Friedman's test. The results revealed that the different concentrations of $\mathrm{CO}_{2}$ gas had no significant impact on the participant's preference for the color, hardness, brittleness, sweetness, and sourness of the dried apricots, while the participant preference for aroma and general acceptance were decreased at the concentrations of 28.6 and $33.4 \mathrm{~mol} \%$ (Table 3).

Table 3. Mean panelists ranking scores of the sensory properties of the dried apricot treated with different concentration of $\mathrm{CO}_{2}$.

\begin{tabular}{cccccccc}
\hline $\begin{array}{c}\text { Concentration } \\
(\mathbf{m o l} \%)\end{array}$ & Aroma & Color & Hardness & Brittleness & Sweetness & Sourness & $\begin{array}{c}\text { General } \\
\text { Acceptance }\end{array}$ \\
\hline Control $=0$ & $3.80 \pm 0.20^{\mathrm{b}}$ & $5.10 \pm 0.23^{\mathrm{a}}$ & $2.10 \pm 0.18^{\mathrm{a}}$ & $2.40 \pm 0.26^{\mathrm{a}}$ & $4.30 \pm 0.15^{\mathrm{a}}$ & $3.30 \pm 0.26^{\mathrm{a}}$ & $4.80 \pm 0.29^{\mathrm{c}}$ \\
9.1 & $3.70 \pm 0.26^{\mathrm{b}}$ & $5.10 \pm 0.23^{\mathrm{a}}$ & $2.00 \pm 0.21^{\mathrm{a}}$ & $2.10 \pm 0.31^{\mathrm{a}}$ & $4.40 \pm 0.26^{\mathrm{a}}$ & $3.20 \pm 1.35^{\mathrm{a}}$ & $4.90 \pm 0.23^{\mathrm{c}}$ \\
16.7 & $3.60 \pm 0.22^{\mathrm{b}}$ & $4.90 \pm 0.23^{\mathrm{a}}$ & $2.00 \pm 0.21^{\mathrm{a}}$ & $2.00 \pm 1.33^{\mathrm{a}}$ & $4.10 \pm 1.37^{\mathrm{a}}$ & $3.60 \pm 1.47^{\mathrm{a}}$ & $4.30 \pm 0.26^{\mathrm{bc}}$ \\
23.1 & $3.70 \pm 0.21^{\mathrm{b}}$ & $4.90 \pm 0.18^{\mathrm{a}}$ & $2.10 \pm 0.21^{\mathrm{a}}$ & $1.90 \pm 0.27^{\mathrm{a}}$ & $3.50 \pm 1.45^{\mathrm{a}}$ & $3.60 \pm 1.42^{\mathrm{a}}$ & $4.20 \pm 0.29^{\mathrm{bc}}$ \\
28.6 & $2.60 \pm 0.26^{\mathrm{a}}$ & $4.70 \pm 1.36^{\mathrm{a}}$ & $2.20 \pm 0.21^{\mathrm{a}}$ & $1.90 \pm 0.27^{\mathrm{a}}$ & $4.633 \pm 0.56^{\mathrm{a}}$ & $3.50 \pm 0.42^{\mathrm{a}}$ & $3.40 \pm 0.34^{\mathrm{ab}}$ \\
33.4 & $2.00 \pm 0.25^{\mathrm{a}}$ & $4.90 \pm 0.27^{\mathrm{a}}$ & $2.20 \pm 0.13^{\mathrm{a}}$ & $2.20 \pm 0.29^{\mathrm{a}}$ & $4.30 \pm 0.36^{\mathrm{a}}$ & $3.60 \pm 0.34^{\mathrm{a}}$ & $2.40 \pm 0.26^{\mathrm{a}}$ \\
& $\chi^{2}=26.83$ & $\chi^{2}=2.22^{2}$ & $\chi^{2}=1.63$ & $\chi^{2}=1.87$ & $\chi^{2}=4.83$ & $\chi^{2}=1.67$ & $\chi^{2}=28.67$ \\
Friedman's & $\mathrm{df}=5$ & $\mathrm{df}=5$ & $\mathrm{df}=5$ & $\mathrm{df}=5$ & $\mathrm{df}=5$ & $\mathrm{df}^{2}=5$ & $\mathrm{df}=5$ \\
test: & $p=0.0000006$ & $p=0.817^{2}$ & $p=0.898$ & $p=0.867$ & $p=0.963$ & $p=0.894$ & $p=0.000002$ \\
\hline
\end{tabular}

Means ( \pm standard error) with different letters within each column are statistically different according to the Friedman's test.

RGB pictures taken with the digital camera and colorimetric factors $\left(\mathrm{L}^{*}, \mathrm{a}^{*}\right.$, and $\left.\mathrm{b}^{*}\right)$ of the dried apricot treated by $\mathrm{CO}_{2}$ were shown in Figure 1. In the images taken, the color parameters $\left(\mathrm{L}^{*}, \mathrm{a}^{*}\right.$, and $\left.\mathrm{b}^{*}\right)$ were calculated for all pixels of the samples. Then the mean values of each parameter were estimated for each image. The values of the color parameters $\mathrm{L}^{*}, \mathrm{a}^{*}$, and $\mathrm{b}^{*}$ were calculated as $27.970,23.119$, and 36.397 , respectively. 


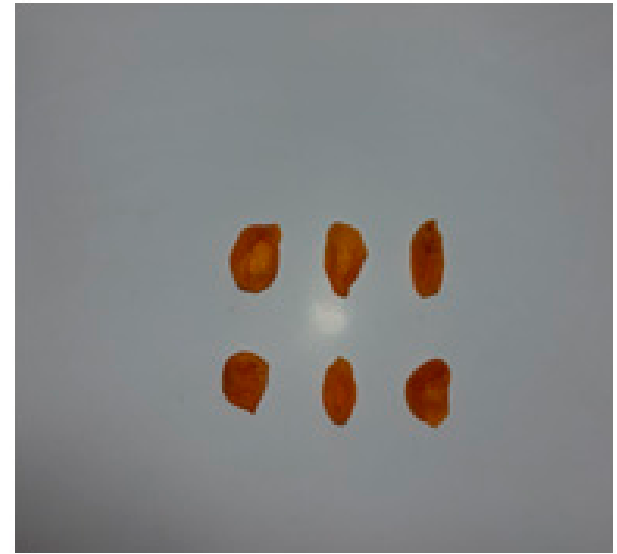

A

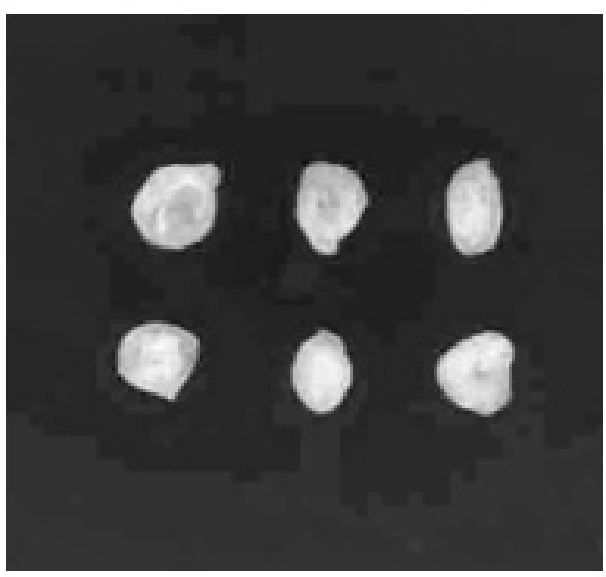

C

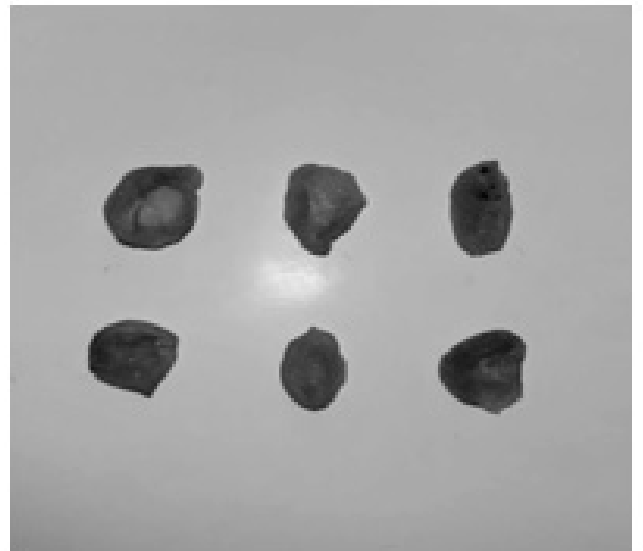

B

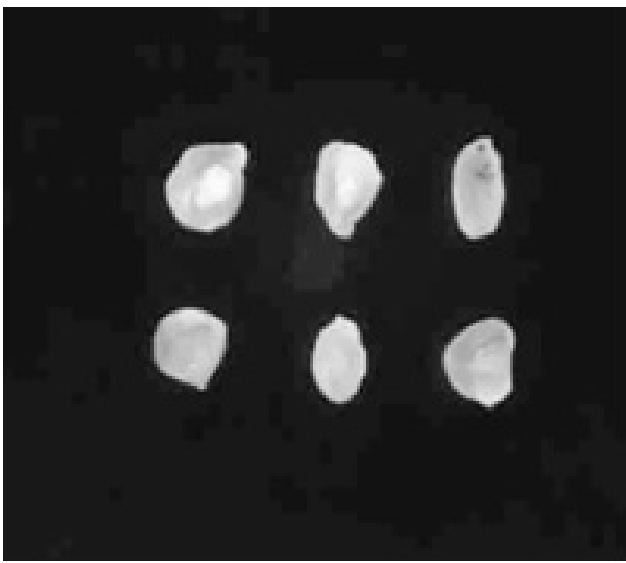

D

Figure 1. Image processing of the dried pieces of apricot: (A) RGB pictures taken with the digital camera; (B) Factor L* (brightness); (C) Factor a* (redness); (D) Factor b* (yellowness). In the images taken, the color parameters $\left(\mathrm{L}^{*}, \mathrm{a}^{*}\right.$, and $\left.\mathrm{b}^{*}\right)$ were calculated for all pixels of the samples, and according to them, the mean values of each parameter were estimated (27.970, 23.119, and 36.397, respectively) through ImageJ $1.50 \mathrm{v}$ software.

Figure 2 displays the increased changes of the brightness $\left(\Delta \mathrm{L}^{*}\right)$, redness $\left(\Delta \mathrm{a}^{*}\right)$, and yellowness $\left(\Delta \mathrm{b}^{*}\right)$ of the treated samples with enhancing $\mathrm{CO}_{2}$ concentrations. Changes in the red color are almost constant at the concentrations between 16.7-23.1 and 28.6-33.4 mol\%. Generally, alterations in the product color factors $\left(\mathrm{L}^{*}, \mathrm{a}^{*}\right.$, and $\left.\mathrm{b}^{*}\right)$ induced by the $\mathrm{CO}_{2}$ treatments are trivial. This degree of color changes triggered by $\mathrm{CO}_{2}$ treatment is usually detectable with bare eyes.

Analysis of $\mathrm{CO}_{2}$ gas impact at the concentration of $33.4 \mathrm{~mol} \%$ on the chemical properties of the dried apricots, including $\mathrm{pH}$, moisture content, acidity, Brix number, reducing sugar, and total sugar, and comparison with those of the control group revealed no significant difference between them (Table 4). Therefore, $\mathrm{CO}_{2}$ gas at the concentration of $33.4 \mathrm{~mol} \%$ would not affect the chemical properties of the control and treated dried pieces of apricot product. 


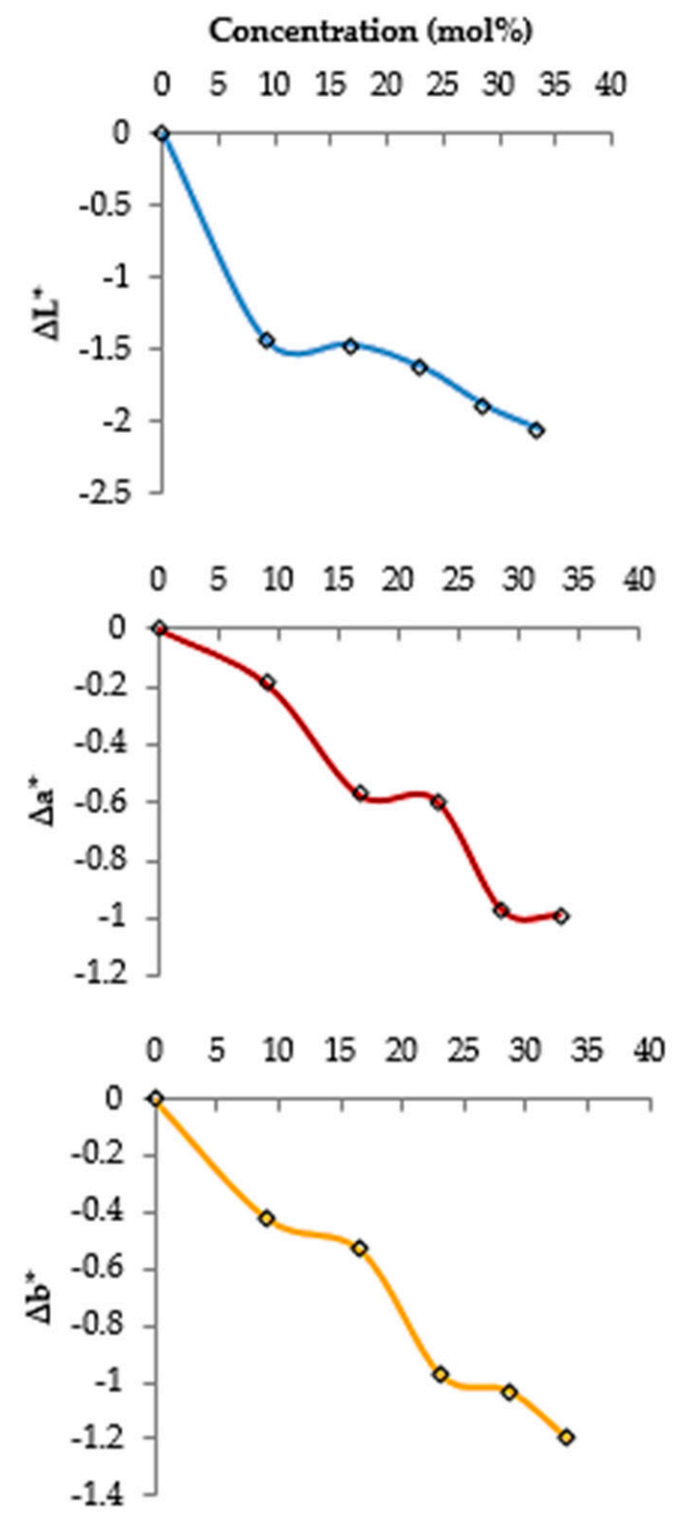

Figure 2. Effects of $\mathrm{CO}_{2}$ concentrations on the color parameters ( $\mathrm{L}^{*}$ (brightness), $\mathrm{a}^{*}$ (redness), and $\mathrm{b}^{*}$ (yellowness)) of the dried apricots.

Table 4. Means \pm standard errors of the chemical properties of the control and treated dried pieces of apricot after $\mathrm{CO}_{2}$ gas treatment at the concentration of $33.4 \mathrm{~mol} \%$.

\begin{tabular}{ccccc}
\hline \multirow{2}{*}{$\begin{array}{c}\text { Chemical } \\
\text { Properties }\end{array}$} & Control & Treatment & \multicolumn{2}{c}{$\begin{array}{c}\text { Comparison of Means } \\
\text { (df = 4) }\end{array}$} \\
\cline { 3 - 5 } & & & $\mathbf{t}$ & Sig. $^{*}$ \\
\hline $\mathrm{pH}$ & $4.17 \pm 0.17$ & $4.30 \pm 0.08$ & -2.42 & 0.73 \\
\hline Acidity & $1.13 \pm 0.29$ & $1.19 \pm 0.27$ & -0.92 & 0.41 \\
\hline Brix & $9.96 \pm 0.44$ & $9.82 \pm 0.46$ & 0.39 & 0.72 \\
\hline Total sugar & $78.29 \pm 3.07$ & $78.79 \pm 3.92$ & -0.14 & 0.9 \\
\hline Reducing sugar & $56.86 \pm 3.72$ & $57.70 \pm 4.67$ & -0.20 & 0.86 \\
\hline Moisture & $10.30 \pm 0.30$ & $10.43 \pm 1.70$ & -0.14 & 0.9 \\
\hline
\end{tabular}

* Since the significant value is more than 0.05 , tested means have no significant difference in each control and treatment row, according to the $t$ test at $p<0.05$. df and sig. are degree of freedom and significant, respectively. 


\section{Discussion}

In current research, the mortality rates of two pest species were enhanced with increasing $\mathrm{CO}_{2}$ concentration. The highest mortality, $78.0 \%$ and $90.5 \%$ for the adults of $T$. castaneum and R. dominica, respectively, was at the concentration of $33.4 \mathrm{~mol} \%$. Kells et al. [33] noticed the increasing $\mathrm{CO}_{2}$ concentration from 25 to $50 \mathrm{ppm}$ to enhance the larval mortality of Indian meal moth (Plodia interpunctella Hübner) from 77 to $94.5 \%$. Riudavets et al. [34] reported that nine storage pests could be controlled by the $\mathrm{CO}_{2}$ pressures of 15 and $20 \mathrm{bar}$ within the time periods of 15,30 , and $60 \mathrm{~min}$. In their study, $5.5 \%$ and $100 \%$ of the mortality of $R$. dominica adults were observed at the pressures of 15 and 20 bar after 15 min-exposure time, respectively. Accordingly, considering about $90 \%$ mortality by 0.5 bar pressure ( $33.4 \mathrm{~mol} \%$ ) of $\mathrm{CO}_{2}$ in the present study, it will be possible to increase the mortality of $R$. dominica by increasing gas pressure (concentration) and exposure time. In research carried out by Sayeda and Hashem [35], the elevated mortality rate of Indian meal moth larvae from 38.9 to $77.8 \%$ was observed with increasing $\mathrm{CO}_{2}$ concentration from 40 to $80 \%$ during $24 \mathrm{~h}$ of fumigation. These researchers reported $\mathrm{CO}_{2}$ concentrations of $40 \%$ and $80 \%$ to lead to $35 \%$ and $71.7 \%$ larval mortality of almond moth (Ephestia cautella (Walker)), respectively. They experienced more vulnerabilities of the eggs and pupae of both species to the gas concentrations in comparison with larvae. At the concentration of $80 \%, 5$ and 7 days required for full mortality of egg and pupal and larvae, respectively [35]. In the study of Wong-Corral et al. [36], increasing $\mathrm{CO}_{2}$ concentration led to the enhanced mortality of Mexican bean weevil, Zabrotes subfasciatus (Boheman). After 2 days of treatment, gas concentration of $90 \%$ resulted in complete mortality, while the concentrations of 70 and $50 \%$ were required for complete mortality after 3 and 4 days of fumigation, respectively. However, they found that the adults of cowpea weevil and bean bruchid (Acanthoscelides obtectus (Say)) were more susceptible to the gas concentrations than Mexican bean weevil adults. In the research of Sadeghi et al. [37], the ozone concentration of $2 \mathrm{ppm}$ and time period of $15 \mathrm{~min}$ resulted in the lowest mortality of the adults of the sawtoothed grain beetle (Oryzaephilus surinamensis L.) and larvae of flour moth E. kuehniella, while the concentration of $5 \mathrm{ppm}$ and time of $90 \mathrm{~min}$ led to complete mortalities. These findings, about the susceptibility of stored-products insect pests to $\mathrm{CO}_{2}$ gas, supports the results of current investigation. This is also congruent with our results, which showed increased mortality of the storage insects by elevating $\mathrm{CO}_{2}$ gas concentrations.

In the present study, no significant impacts on the color, aroma, sweetness, sourness, brittleness, hardness, and general acceptance of the dried apricot were caused by enhancing the gas concentration of $\mathrm{CO}_{2}$. Similarly, Sadeghi et al. [37] reported no significant influences of increasing ozone concentration and times of fumigation on the color, sweetness, sourness, brittleness, hardness, and general acceptance of dried figs and raisins, but they witnessed considerable effects on the aroma of the two products. Of course, they concluded that due to the volatility of ozone gas, their unpleasant odors could disappear over time. Accordingly, documented effects of $\mathrm{CO}_{2}$ concentrations on the aroma of dried apricots can be removed over time. In the test of color changes of the product surface, the increases in $\mathrm{CO}_{2}$ gas pressures were observed to have trivial effects on the surface colors of the dried apricot samples, which was not detectable with bare eye. In this regard, Sadeghi et al. $[37,38]$ reported that increasing ozone concentrations $(2,3$, and $5 \mathrm{ppm})$ and exposure times (15, $30,45,60$, and $90 \mathrm{~min}$ ) had no significant effects on the colorimetric factors of their raisins and figs.

Furthermore, $\mathrm{CO}_{2}$ gas at the concentration of $33.4 \mathrm{~mol} \%$ had no impacts on the chemical properties ( $\mathrm{pH}$, Brix value, acidity, reducing sugar, total sugar, and moisture content) of the dried apricots. These results were consistent with the findings of Inserra et al. [23], who reported insignificant impacts of sulfur on the moisture content, Brix value, and total sugar of dried apricot. The moisture percentage, $\mathrm{pH}$, acidity, Brix value, reducing sugar, and total sugar contents of the dried apricots (Alkia cultivar) treated with sulfur were measured as be $22.5 \%, 4.2 \%, 1.8 \%, 68.1 \%, 64.4 \%$, and $87.9 \%$, respectively. These results, regarding no significant differences in chemical properties of treated and untreated dried 
apricot, are in agreement with those obtained in our study. The reason for the discrepancy of the measured Brix values in the study of Inserra et al. [23] and present study (68.1\% and $9.82 \%$, respectively) is related to the differences in the measurement methods, i.e., amounts of water added to the samples. In addition, the varied moisture contents can be attributed to the differences in the durations of the drying methods and their varieties [23].

\section{Conclusions}

According to the present results, fumigation of $\mathrm{CO}_{2}$ caused significant toxicity on the adults of R. dominica and T. castaneum so that 20.19 and $27.02 \mathrm{~mol} \%$ of the gas were adequate to kill $50 \%$ of pests within $24 \mathrm{~h}$, respectively. The use of $\mathrm{CO}_{2}$ gas, despite the toxicity to insect pests, had no significant side-effects on the sensory and chemical properties of the treated apricot specimens. Consequently, the prospective insecticidal activity of $\mathrm{CO}_{2}$ gas offers an efficient tool to control the cosmopolitan insect pests $R$. dominica and T. castaneum, with no detrimental side-effects on stored-apricots. The main advantage of using carbon dioxide in preserving dried fruits such as apricots from pests is no necessity of complex and expensive devices. In other words, by using the cylinders containing this gas and adjusting the desired pressure, along with an impermeable covering of the warehouse, the control procedure can be carried out satisfactorily [39].

Author Contributions: Conceptualization, R.S., F.A. and F.H.; methodology, F.H.; formal analysis F.H. and A.E.; investigation, R.S., F.H. and A.E.; writing—original draft preparation, R.S., F.H., A.E., F.A., A.J. and F.P.; writing—review and editing, R.S., A.E. and F.P.; supervision, R.S., F.A. and A.J. All authors have read and agreed to the published version of the manuscript.

Funding: This research received no external funding.

Institutional Review Board Statement: Not applicable.

Informed Consent Statement: Not applicable.

Data Availability Statement: The data that support the findings of this study are available upon request from the authors.

Acknowledgments: The authors are grateful for financial support and valuable technical assistance to Department of Entomology and Plant Pathology, College of Aboureihan, University of Tehran. We acknowledge the Department of Food Technology, College of Aboureihan, University of Tehran for providing facilities to conduct this work.

Conflicts of Interest: The authors declare no conflict of interest.

\section{References}

1. Kan, T.; Gundogdu, M.; Ercisli, S.; Muradoglu, F.; Celik, F.; Gecer, M.K.; Kodad, O.; Zia-Ul-Haq, M. Phenolic compounds and vitamins in wild and cultivated apricot (Prunus armeniaca L.) fruits grown in irrigated and dry farming conditions. Boil. Res. 2014, 47, 46. [CrossRef]

2. Fellows, P.J. Food Processing Technology, Principles and Practice, 2nd ed.; Woodhead Publishing Limited: Cambridge, UK, 2000; pp. 378-405.

3. (FAO) Food and Agriculture Organization. Countries by Commodity; FAO: Rome, Italy, 2018.

4. Burks, S.C.; Johnson, J.A. Biology, Behavior, and Ecology of Stored Fruit and Nut Insects. In Stored Product Protection, 1st ed.; Hagstrum, D.W., Phillips, T.W., Cuperus, G., Eds.; Kansas State Research and Extension: Kansas, TX, USA, 2012; pp. 21-33.

5. Moreda, G.P.; Ruiz-Altisent, M. Quality of agricultural products in relation to physical conditions. In Encyclopedia of Agrophysics, 1st ed.; Gliński, J., Horabik, J., Lipiec, J., Eds.; Springer: Dordrecht, The Netherlands, 2011; pp. 669-678. [CrossRef]

6. Heckel, D.G. Insecticide resistance after silent spring. Science 2012, 337, 1612-1614. [CrossRef]

7. Nicolopoulou-Stamati, P.; Maipas, S.; Kotampasi, C.; Stamatis, P.; Hens, L. Chemical pesticides and human health: The urgent need for a new concept in agriculture. Front. Public Health 2016, 4, 148. [CrossRef] [PubMed]

8. Zikankuba, V.L.; Mwanyika, G.; Ntwenya, E.; James, A. Pesticide regulations and their malpractice implications on food and environment safety. Cogent Food Agric. 2019, 5, 1601544. [CrossRef]

9. Panna, K.S.S. Methyl Bromide Phase-Out Strategies; a Global Compilation of Laws and Regulations. 1999. Available online: http://www.unep.fr/ozonaction/information/mmcfiles/3020-e.pdf (accessed on 24 May 2021).

10. Damalas, C.A.; Eleftherohorinos, I.G. Pesticide exposure, safety issues, and risk assessment indicators. Int. J. Environ. Res. Public Health 2011, 8, 1402-1419. [CrossRef] 
11. Ebadollahi, A.; Ziaee, M.; Palla, F. 2020: Essential oils extracted from different species of the Lamiaceae plant family as prospective bioagents against several detrimental pests. Molecules 2020, 25, 1556. [CrossRef]

12. Palla, F.; Bruno, M.; Mercurio, F.; Tantillo, A.; Rotolo, V. Essential oil as natural biocides in conservation of cultural heritage. Molecules 2020, 25, 730. [CrossRef] [PubMed]

13. Cao, Y.; Xu, K.; Zhu, X.; Bai, Y.; Yang, W.; Li, C. Role of modified atmosphere in pest control and mechanism of its effect on insects. Front. Physiol. 2019, 10, 206. [CrossRef]

14. Hasan, M.M.; Aikins, M.J.; Schilling, W.; Phillips, T.W. Efficacy of controlled atmosphere treatments to manage arthropod pests of dry-cured hams. Insects 2016, 7, 44. [CrossRef]

15. Khalil, S.S.H.; Ahmed, S.S.; Abd El-Rahman, S.F.; Khalifa, E.A.A. Comparative effects of carbon dioxide concentration in moified temperature and pressure conditions on adults and larvae of the red flour beetle, Tribolium castaneum (Herbst) (Coleoptera: Tenebrionidae). Coleop. Bull. 2020, 74, 127-135. [CrossRef]

16. Leelaja, B.C.; Rajashekar, Y.; Reddy, P.V.; Begum, K.; Rajendran, S. Enhanced fumigant toxicity of allyl acetate to stored- product beetles in the presence of carbon dioxide. J. Stored Prod. Res. 2006, 43, 45-48. [CrossRef]

17. Cheng, W.; Lei, J.; Ahn, J.E.; Liu, T.X.; Zhu-Salzman, K. Effects of decreased $\mathrm{O}_{2}$ and elevated $\mathrm{CO}_{2}$ on survival, development, and gene expression in cowpea Bruchids. J. Insect Physiol. 2012, 58, 792-800. [CrossRef] [PubMed]

18. Valizadegan, O.; Pourmirza, A.A.; Safaralizadeh, M.H. The impact of carbon dioxide in stored-product insect treatment with phosphine. Afr. J. Biotechnol. 2012, 11, 6377-6382. [CrossRef]

19. Dhouibi, M.H.; Hermi, N.; Hajjem, B.; Hammami, Y.; Arfa, M.B. Efficacy of $\mathrm{CO}$ and $\mathrm{CO}_{2}$ treatment to control the stored-date insects, Ephestia kuehniella and Ectomyelois ceratoniae for organic dates production. Int. J. Agric. Innov. Res. 2015, 3, 1473-2319.

20. Sun, D.W.; Brosnan, T. Inspection and grading of agricultural and food products by computer vision systems-a review. J. Comput. Electron. Agric. 2002, 36, 193-213. [CrossRef]

21. Leon, K.; Mery, D.; Pedreschi, F.; Leon, J. Color measurement in $\mathrm{L}^{*} \mathrm{a}^{*} \mathrm{~b}^{*}$ units from RGB digital images. J. Food Int. Res. 2006, 39, 1084-1091. [CrossRef]

22. Sadeghi, R.; Seyedabadi, A.; Mirabi Moghaddam, R. Microwave application for controlling Oryzaephilus surinamensis Insects infesting dried figs and evaluation of product color changes using an image processing technique. J. Food Prot. 2018, 82, 184-188. [CrossRef]

23. Inserra, L.; Cabaroglu, T.; Sen., K.; Arena, E.; Ballistreri, G.; Fallico, B. Effect of sulphuring on physicochemical characteistics and aroma of dried Alkaya apricot: A new Turkish variety. J. Agric. For. 2017, 41, 59-68. [CrossRef]

24. Rees, D. Insects of Stored Grain: A Pocket Reference, 2nd ed.; CSIRO Publishing: Collingwood, Australia, 2007 ; p. 77.

25. Sarwar, M. Protecting dried fruits and vegetables against insect pests invasions during drying and storage. Am. J. Market. Res. 2015, 1, 142-149.

26. Sousa, A.H.; Faroni, L.R.D.A.; Guedes, R.N.C.; Totola, M.R.; Urruchi, W.I. Ozone as a management alternative against phosphineresistant insect pests of stored products. J. Stored Prod. Res. 2008, 44, 379-385. [CrossRef]

27. Vayias, B.J.; Athanassiou, C.G.; Kavallieratos, N.G.; Tsesmeli, C.D.; Buchelos, C.T. Persistence and efficacy of two diatomaceous earth formulations and a mixture of diatomaceous earth with natural pyrethrum against Tribolium confusum Jacquelin du Val (Coleoptera: Tenebrionidae) on wheat and maize. Pest Manag. Sci. 2006, 62, 456-464. [CrossRef]

28. Subramanyam, B.; Toews, M.D.; Ileleji, K.E.; Maier, D.E.; Thompson, G.D.; Pitts, T.J. Evaluation of spinosad as a grain protectant on three Kansas farms. Crop Prot. 2007, 26, 1021-1030. [CrossRef]

29. (INSO) Iranian National Standards Organization. Sensory Evaluation-Methodology-Tips for Monitoring the Performance of a Quantitative Sensory Evaluation Team, Standard No. 18294; NISO: Tehran, Iran, 2014.

30. El-Arem, A.; Guido, F.; Behija, S.E.; Manel, I.; Nesrine, I.; Ali, Z.F.; Mohamed, H.; Noureddine, H.; Lotfi, A. Chemical and aroma volatile compositions of date palm (Phoenix dactylifera L.) fruits at three maturation stages. J. Food Chem. 2011, 127, 1744-1754. [CrossRef]

31. Parvaneh, V. Quality Control of Food Chemical Experiments, 7th ed.; University of Tehran Publications: Tehran, Iran, 2013; pp. 210-247.

32. Abbott, W.S. A method of computing the effectiveness of an insecticide. J. Econ. Entomol. 1925, 18, 265-267. [CrossRef]

33. Kells, S.A.; Mason, L.J.; Maier, D.E.; Woloshuk, C.P. Efficacy and fumigation characteristics of ozone in stored maize. J. Stored Prod. Res. 2001, 37, 371-382. [CrossRef]

34. Riudavets, J.; Castañé, C.; Alomar, O.; Pons, M.J.; Gabarra, R. The use of carbon dioxide at high pressure to control nine stored-product pests. J. Stored Prod. Res. 2010, 46, 228-233. [CrossRef]

35. Sayeda, A.; Mohammad, Y.H. Susceptibility of different life stages of Indian meal moth Plodia interpunctella (Hübner) and almond moth Ephestia cautella (Walker) (Lepidoptera: Pyralidae) to modified atmospheres enriched with carbon dioxide. J. Stored Prod. Res. 2012, 51, 49-55. [CrossRef]

36. Wong-Corral, F.J.; Castañé, C.; Riudavates, J. Lethal effects of $\mathrm{CO}_{2}$-modified atmosphere for the control of three Bruchidae species. J. Stored Prod. Res. 2013, 55, 62-67. [CrossRef]

37. Sadeghi, R.; Mirabi Moghaddam, R.; Taghizadeh, M. Application of ozone to control dried fig pests Oryzaephilus surinamensis (Coleoptera: Silvanidae) and Ephestia kuehniella (Lepidoptera: Pyralidae) and its organoleptic properties. J. Econ. Entomol. 2017, 110, 2052-2055. [CrossRef] 
38. Sadeghi, R.; Seyedabadi, A.; Mirabi Moghaddam, R. Evaluation of microwave and ozone disinfections on the color characteristics of Iranian export raisins through an image processing technique. J. Food Prot. 2019, 82, 2080-2087. [CrossRef]

39. Navarro, S. The use of modified and controlled atmospheres for the disinfestation of stored products. J. Pest Sci. 2012, 85, 301-322. [CrossRef] 